\title{
Transboundary insects of the current decade: potential of biological control in the Indian context
}

\section{S. Vennila*, Shabistana Nisar and Puran Chandra}

The second decade of the 21 century saw five insects, viz. cassava mealybug Phenacoccus manihoti Matile-Ferrero (Hemiptera: Coccomorpha: Pseudococcidae), desert locust Schistocerca gregaria Forskål (Orthoptera: Acrididae), fall armyworm (FAW; Spodoptera frugiperda (J. E. Smith) (Lepidoptera: Noctuidae), rugose spiralling whitefly, Aleurodicus rugioperculatus Martin (Hemiptera: Aleyrodidae) and southern American pinworm Tuta absoluta (Meyrick) (Lepidoptera: Gelechiidae) invading India having crossed international borders. While early warning system along with potential of testing Metarhizium acridum (Green Muscle ${ }^{\mathrm{TM}}$ ) through the Food and Agricultural Organisation exists for desert locust, an early importation of parasitoid Anagyrus lopezi De-Santis (Hymenoptera:Encyrtidae) against cassava mealybug is the need of the hour. Documentation of versatile native parasitoids (9), predators (3) and pathogens (6) on FAW implies potential of biological control through conservation and augmentative approaches in maize ecosystems. Fortuitous introduction of Encarsia guadeloupae Viggiani (Hymenoptera: Aphelinidae) in the late nineties along with an invasive spiralling whitefly Aleurodicus dispersus offering successful biocontrol of rugose spiralling whitefly indicated long-term sustenance of parasitoids in perennial plantations. Nevertheless, the internally feeding invasive southern American pinworm in open fields and protected tomato cultivation need biological products as a component of integrated pest management. A quick response in terms of delimitation and eradication is anticipated for transboundary insects and is only possible through establishment of an operational national digital reporting system with coordination and collaborations of not only all governmental and private stakeholders of plant protection in India, but also forging cooperation at regional and international levels for timely and effective management of transboundary insects.

Keywords: Biological control, collaboration, conservation, transboundary insects.

RECOGNITION of invasive insects of transboundary nature as a serious threat exacerbated by forces such as globalized movement of people (travel) and commodities (trade), and environmental factors (climate change) to food security has become an established phenomenon. India, in addition to the COVID-19 pandemic in 2020, is witnessing invasions of cassava mealybug Phenacoccus manihoti Matile-Ferrero (Hemiptera: Coccomorpha: Pseudococcidae), with its first record on cassava (Manihot esculenta Crantz) at Thrissur, Kerala ${ }^{1}$ followed by its widespread infestations in the neighbouring state of Tamil Nadu in Southern India ${ }^{1}$ and the upsurge of desert locust (DL; Schistocerca gregaria Forskål; Orthoptera:

The authors are in the ICAR-National Research Centre for Integrated Pest Management, New Delhi 110 012, India.

*For correspondence. (e-mail: svennila96@gmail.com)
Acrididae) with the swarms attaining epidemic proportions in the Rajasthan, Haryana, Punjab, Madhya Pradesh, Maharashtra, Uttar Pradesh and Bihar ${ }^{2}$. The incursion of fall armyworm (FAW; Spodoptera frugiperda (J.E. Smith); Lepidoptera: Noctuidae) first reported from Shivamoga, Karnataka ${ }^{3}$ in 2018 , has not only spread rapidly across all maize-growing states of India ${ }^{4}$, but has established as a regular insect pest of maize with its attack also reported on sorghum and bajra. Rugose spiralling whitefly (RSW), Aleurodicus rugioperculatus Martin (Hemiptera: Aleyrodidae) of American origin was first noticed on coconut from Pollachi, Tamil Nadu and Palakkad, Kerala in 2016, with its current distribution in Tamil Nadu, Karnataka, Kerala, Andhra Pradesh, Goa and Assam across host plants of coconut, banana, mango, sapota, guava, cashew, maize, ramphal, oil palm, Indian almond, water apple, jackfruit and many ornamental plants ${ }^{5}$. South 
American tomato moth, Tuta absoluta (Meyrick) (Lepidoptera: Gelechiidae) is also an invasive insect of the current decade first reported in 2014 (ref. 6) that has spread and established in several states within a short span of time and is now a regular pest of India. Reports of $T$. $a b$ soluta at Bengaluru (Karnataka), Rajendranagar (Telangana $)^{7}$, Ludhiana (Punjab) and Varanasi and Mirzapur (Uttar Pradesh) were available in November 2014, March 2015, September 2016 and January 2017 respectively. It is to be noted that no eradication has occurred in any of the five invasive insects (Figure 1) of the current decade. All are widespread, reproduce faster and feed on a wider host of plants emphasizing their higher threat potential and economic damage to the crops they infest. Ideally, a coordinated response of delimitation and eradication following diagnosis of an invasive insect is needed. However, a significant period goes into confirmation of species identity of the insect. By the time the first report is available, the insects would have already spread to wider geographies of the country. Insect pests of transboundary nature need instant attention considering the management interventions adopted elsewhere in the world and to account for a concerted biocontrol effort, be it native and classical, while handling their onslaught. Considering invasive insects of the current decade, present article discusses the potential and need for biological control attempts as a first and major step for their management to set up a treadmill of environmental-friendly management.

\section{Desert locust}

Desert locust (DL) is unique considering its behaviour as swarms. Given the potential of $100 \%$ crop devastation, its management measures have always been on emergency basis aided by locust warning organizations using chemicals in larger areas when they migrate or breed. The monsoon season of 2010 had an upsurge of DL between October and November confined to Jaisalmer, Rajasthan, infesting 4700 ha that was treated with malathion. DL was absent in 2011, although adults of solitary phase were reported at isolated places in Jaisalmer, Bikaner and Jodhpur in Rajasthan. In 2012-13 with no major developments of DL, solitary phase was noted ${ }^{2}$. While 2016 and 2017 had other species (migratory and tree) of locusts reported and treated, DL crossed borders and caused significant losses to farmers of northwest and central India along the pathway of spread of adult swarms between April and June 2019. In 2020, Rajasthan was put on high alert and swarms entering Madhya Pradesh, Uttar Pradesh, Punjab, Haryana and Gujarat were observed during May and June. The invasion had caused only minor crop losses as most of the rabi harvests were over and few summer crops were in the fields. Use of drones was approved by the Government of India to manage locusts for the first time between May and June 2020. As of the first fortnight of September 2020, the continued intensive surveys and control operations executed during the past months are keeping DL under control in India ${ }^{8}$. Not to be complacent, with the repeated occurrence of DL invasions, our country needs to invest in the solutions of biological control in a larger way using native or imported microbial pesticides. An isolate of fungus Metarhizium acridum (Green Muscle ${ }^{\mathrm{TM}}$ ), a fungal product of LUBILOSA LUtte BIologique contre les LOcustes et SAuteriaux (biological control of locusts and grasshoppers) from fundings by the governments of Canada, The Netherlands, Switzerland, Britain and USA has proven to work better when applied on time to hopper bands of DL before swarming commences. In 2020, Food and Agricultural Organisation (FAO) delivered the product (Green Muscle ${ }^{\mathrm{TM}}$ ) acclaimed as a biological solution with proven results in Somalia, Kenya and Ethiopia. Samples were also sent to Uganda, Pakistan and India, where the locust situation is getting worse ${ }^{9}$. It is high time that India needs to look into the efficacy of native and diversified isolates of Metarhizium alongside the samples of Green Muscle ${ }^{\mathrm{TM}}$, utilizing the prevalent DL population to achieve higher degree of future preparedness and success in its management.

\section{Cassava mealybug}

The cassava crop having significant economic value in agro and food industries is mostly grown without insecticidal applications in India. Even if desired, an effective insecticidal application for a crop growing taller with top canopy after 4-5 months is difficult. Following confirmation of cassava mealybug (CMB) infestations at Thrissur $^{10}$ in January 2020 (ref. 1), its spread was noticed into neighbouring districts of Tamil Nadu, wherein damage varied from entire fields of germinated and early-stage crops infested by $P$. manihoti to $9 \%-42 \%$ in other fields by June 2020. Since then, more fields and widespread infestations of CMB are coming to attention through farmers, state department personnel and researchers. Inadequate control of CMB using botanicals, biological and chemical insecticides was communicated by cassava farmers of Tamil Nadu during surveys, although no insecticide with label claim exists ${ }^{11}$. Outside of India, a decade ago, CMB-specific encyrtid parasitoid Anagyrus lopezi De-Santis (Hymenoptera:Encyrtidae; Synonyms: Epidinocarsis lopezi, Apoanagyrus lopezi) native to South America introduced in Africa was reported to be effective in suppressing CMB. Thailand introduced $A$. lopezi against CMB in 2009 from Benin, West Africa, and made field releases during mid-2010 enabling recovery of cassava production. Anagyrus lopezi introductions into Lao PDR, Cambodia and Vietnam (2011-13) and its successful establishment have been reported. Classical biological control of CMB was achieved using $A$. lopezi in Thailand 


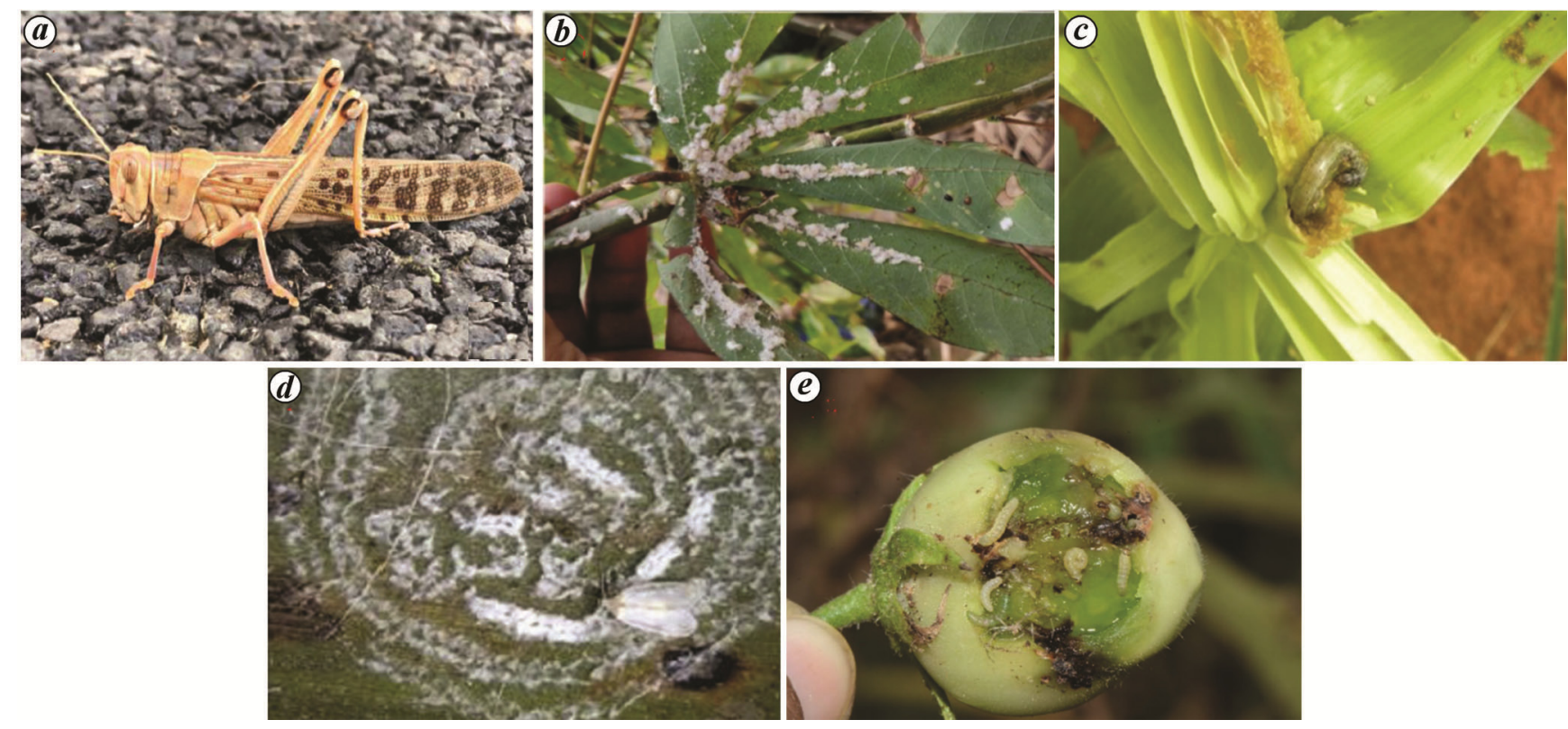

Figure 1. Transboundary insects of the current decade in India (source: https://www.nbair.res.in). a, Desert locust: Schistocerca gregaria (Forskål). b, Cassava mealybug: Phenacoccus manihoti (Matile-Ferrero). c, Fall armyworm: Spodoptera frugiperda (J. E. Smith). d, Rugose spiralling whitefly: Aleurodicus disperses (Martin). e, South American tomato moth: Tuta absoluta (Meyrick).

and Indonesia. Studies on host susceptibility, preference and suitability indicated that $A$. lopezi could develop only on $\mathrm{CMB}^{12}$ and the parasitism ranged from $10 \%$ to $57 \%$ (ref. 13). A large-scale biological control campaign by the International Institute of Tropical Agriculture (IITA), Benin, in collaboration with numerous national and international organizations led to the successful control of $P$. manihoti through the introduction and establishment of $A$. lopezi. Now the parasitoid wasp has established itself in 26 African and 4 Asian countries, imparting a satisfactory reduction in the population density of $\mathrm{CMB}$ in most farmers' fields, thus averting the need for the use of insecticides. CMB sample collections from unsprayed cassava fields of Tamil Nadu have established no fortuitous introduction of $A$. lopezi into India ${ }^{1}$. Absence of other parasitoid records in cassava ecosystems of India also exempts any interspecific competition that could limit the potential of $A$. lopezi on CMB, if introduced. The National Bureau of Agricultural Insect Resources (NBAIR), Bengaluru has reported that predators, viz. Cardiastethus sp. (Hemiptera: Anthocoridae), Spalgis epeus (Lepidoptera: Lycaenidae), Hyperaspis maindroni Sicard and Scymnus coccivora (Coleoptera: Coccinellidae) were found feeding upon the mealybug stages in cassava ecosystems ${ }^{1,10}$. NBAIR, Bengaluru has been successful in operationalizing classical biological control of papaya mealybug ( $\mathrm{Pa}$ racoccus marginatus Williams \& Granara de Willink), an invasive insect, in 2008 through importation of three parasitoids, viz. Acerophagus papayae, Anagyrus loecki and Pseudleptomastix mexicana from Puerto Rico complying with mandatory safety procedures and specificity tests under quarantine. Anagyrus papaya was found effective against $P$. marginatus. Its mass production and field releases in large scale had reduced the incidence in southern India from $49 \%$ to $3 \%$ over a period of two years (2010-12) and an average incidence of $0-2 \%$ during 2017-18 across mulberry-growing areas in Tamil Nadu, Karnataka, Kerala, Maharashtra and Gujarat ${ }^{14}$. Awareness creation among farmers and continuous monitoring of both $P$. marginatus and A. papayae supplemented with regular supply and conservation of the parasitoid had resulted in classical biological control of papaya mealybug. Hence, given the CMB status it is only prudent to import the CMB-specific parasitoid $A$. lopezi at the earliest through International Institute of Tropical Agriculture, Benin following all official formalities. Protecting cassava cultivation in Kerala and Tamil Nadu from CMB onslaughts thus depends on importation of $A$. lopezi. Importation, safety testing under quarantine, mass production and field releases of $A$. lopezi are the immediate steps and the way forward for India.

\section{Fall armyworm}

Fall armyworm (FAW), a native insect to tropical and subtropical regions of America during the 17th century invaded Asia in 2018, with its spread across southeast Asian countries by 2019. Invasion of FAW into India on maize was during May 2018 (ref. 3). Notwithstanding its host preference for maize and faster distribution across all maize-growing geographies of India, its potential 
ability to infest cereal crops like rice, sorghum and pearl millet exists. By virtue of India having insects like stem borers, semi loopers, pod borers and bollworms as regular and polyphagous lepidopterans across many crops of both mono and dicots, the production systems of any given region are not devoid of native natural enemies of insects such as parasitoids, predators and pathogens. Ever since the introduction of FAW, natural parasitism by hymenopterans, viz. Telenomus sp. (Platygastridae), Trichogramma sp. (Trichogrammatidae), Chelonus sp., Glyptapanteles creatonoti (Viereck) and Cotesia sp. of Braconidae, Phanerotoma sp. and Campoletis chlorideae Uchida of Ichneumonidae have been documented in maize ecosystems of India ${ }^{15}$. Natural levels of parasitism by braconid wasps (Chelonus formosanus Sonan, an egg larval parasitoid ${ }^{16}$ and Coccygidium transcaspicum (Kokujev), a larval parasitoid $\left.^{17}\right)$ were often very high $(20 \%-70 \%)$. Fly parasitoids such as Archyta marmoratus (Tachinidae: Diptera) and earwig predator, Forficula sp. also devour FAW under natural field conditions. Pentatomid bugs like Eocanthecona furcellata and Andrallus spinidens were reported to prey on FAW larvae ${ }^{18}$. Many other common FAW predators of unidentified species include spiders, predatory wasps, ladybird beetles, mirid bugs, earwigs and rove beetles. Nuclear polyhedrosis virus (NPV of Sf) ${ }^{19}$ and Nomuraea rileyi of $S$. frugiperda larvae have been documented ${ }^{15}$. Widening niche and adaptation of local biogents of Spodoptera spp. and other lepidopteran insects are the main reasons for higher diversity of native natural enemies documented for $S$. frugiperda in India. With diverse natural control options obviously operating in fields against FAW, it becomes imperative to instil a conservation biocontrol-based FAW management strategy. A nano-based slow-release pheromone dispenser for mass trapping of FAW male moths has been licensed for commercialization to ensure its availability to farmers ${ }^{20}$. The recommended package of practices in maize ecosystems for FAW management accounts for diverse native natural fauna and their role with prioritization for applied biocontrol options, which include botanicals, parasitoids and microbial insecticides instead of chemical insecticides. First spray with 5\% neem seed-kernel extract or azadiractin, $1500 \mathrm{ppm} \mathrm{(1} \mathrm{litre/acre)} \mathrm{after} \mathrm{observation} \mathrm{of} \mathrm{one}$ moth/trap/day (trap catch threshold) in FAW pheromone traps or $5 \%$ larval plant infestation or augmentative release of egg parasitoids, viz. Telenomus remus (10,000/ha) or Trichogramma pretiosum/Trichogramma chilonis@125,000/ha at seven and 14 days with the trap catch of one moth/day is recommended. Options for whorl application of microbials, viz. Bacillus thuringiensis var. kurstaki(400 g/acre)@2 g/l or Metarhizium anisopliae or Beauveria bassiana (spore count of $1 \times$ $10^{8} \mathrm{cfu} / \mathrm{g} ; 1 \mathrm{~kg} / \mathrm{acre}$ ) or Spodoptera frugiperda nuclear polyhedrosis virus (SfNPV; $600 \mathrm{ml} /$ acre) or entomopathogenic nematode (EPN; $4 \mathrm{~kg} /$ acre) at 5-10\% infestation (sowing to six leaf stage), and/or $>10 \%$ infestation during seven leaf stage to flowering and $>10 \%$ ear damage exist $^{21,22}$. With natural and organic farming given emphasis currently, the priority of managing an invasive pest along the lines of exploiting natural and applied biological control would bring economic and environmental dividends. Biocontrol-based IPM tested against farmer practices for FAW management had shown 38.3\% and $42.3 \%$ yield gain per acre during rabi and kharif respectively in Karnataka ${ }^{23}$. It is to be noted that web-based FAW portals of $\mathrm{FAO}^{24}$ and CABI offer a wide range of news, research, practical extension materials, videos and other resources. The mobile app on FAW Monitoring and Early Warning System (FAMEWS) implemented by FAO is a step forward to aid better management decisions. While FAO has launched 'Global Action for Fall Armyworm Control' in 2020 with the objectives of establishing global, regional, national and farmer-level coordination and collaboration, $\mathrm{CABI}$, UK is bringing together the research and associated stakeholders to a common web platform $^{25}$. ASEAN Action Plan on FAW Control supports around 10 countries to respond, monitor and manage FAW across the region ${ }^{26}$, and India should integrate itself through an efficient and effective participation.

\section{Rugose spiralling whitefly}

Rugose spiralling whitefly (RSW) is an alien invasive species reported in 2016 across coconut plantations in southern states of India (Tamil Nadu and Kerala). It has spread as far as Assam in the North East and Goa on the west coast with host records amongst crops from plantation, fruit and ornamental categories ${ }^{5}$. Two species of Encarsia (E. dispersa Polaszek and E. guadeloupae Viggiani; Hymenoptera: Aphelinidae) were fortuitous introductions along with the host spiralling whitefly $A$. dispersus in late nineties of the last century in South India $^{27}$. E. guadeloupae completely displaced $E$. dispersa within a short span of 2-3 years ${ }^{28}$ and when RSW invaded coconut plantations in 2016, the aphelinid E. guadeloupae played an instant role in preventing severe outbreaks with about $56-82 \%$ parasitization under natural conditions. Even E. dispersa was reported for the first time on RSW, although the extent of parasitism was $<5 \%$ as against overall parasitism of $60 \%-70 \%$ along with $E$. guadeloupae $e^{29}$. Parasitism levels of $40 \%-70 \%$ and $20 \%-$ $60 \%$ on banana ${ }^{29}$ and coconut ${ }^{30}$ respectively, by E. guadeloupae was reported across Tamil Nadu and Kerala. Considering the natural build-up of E. guadeloupae in RSW endemic areas, pursuit of strategies for awareness campaigns, training in identification, mass production and its distribution with no application of chemical insecticides had enhanced niche survival of the parasitoid. The coconut growers were advised to grow banana and Canna 
indica as banker plants for conservation of the parasitoid. ICAR-NBAIR also identified and developed a highly effective entomopathogenic fungus, Isaria fumosorosea (ICAR-NBAIR pfu-5) and field tested it across Andhra Pradesh, Karnataka, Kerala, Tamil Nadu, West Bengal and Maharashtra. The fungus was effective in killing all the life stages of RSW with mortality up to $91 \%$. Talc, rice grain and oil formulations developed with long shelflife are in huge demand by the coconut farming community. I. fumosorosea was also found effective against RSW infesting oil palm ${ }^{31}$. The case of effective management of invasive RSW stands as an example of swift action of utilizing biological control approaches in the current decade.

\section{South American tomato moth}

Invasion of South American tomato moth (SATM) in 2014 in Karnataka ${ }^{6}$ followed by its steady spread across the central and northern states during subsequent years has rendered T. absoluta as a regular and key pest of tomato. Four hymenopteran parasitoids, viz. Trichogramma achaeae Nagaraja and Nagarkatti, Neochrysocharis formosa (Westwood), Habrobracon sp. and Goniozus sp. were observed to be associated with $T$. $a b$ soluta in southern India. Laboratory evaluation of trichogrammatids indicated parasitization levels 5.0\%, 51.1\% and $68.2 \%$ of $T$. absoluta eggs by $T$. achaeae, T. pretiosum and Trichogrammatoidea bactrae Nagaraja respectively $^{32}$. Spiders (Argiope sp.) and mirid bugs (Nesidiocoris tenuis Reuter) were also found predating on T. absoluta ${ }^{6,7}$. Natural incidence of Metarhizium anisopliae on T. absoluta larvae was up to $35 \%$ under rainy and humid weather. ICAR-Indian Institute of Horticultural Research, Bengaluru has developed Integrated Pest Management (IPM) strategies for T. absoluta over the years (2017-20) for polyhouses and open fields ${ }^{33}$. Yellow light traps captured $46 \%$ of $T$. absoluta females at times of low to moderate population levels of T. absoluta, in turn significantly reducing leaf and fruit damage. Under open cultivation, use of pheromone traps (8/acre), light traps (5/acre), release of egg parasitoid, $T$. pretiosum $(75,000 /$ ha) five times at weekly intervals starting from first notice of adults in traps and alternating sprays of Metarhizhium anisopliae (1 litre/ha) and Bacillus thuringiensis $(0.5 \mathrm{~kg} / \mathrm{ha})$ led to $7 \%$ fruit damage as against $32 \%$ damage of tomato in control plots. While azadirachtin $1 \%$ (1.5 1/ha) application at low adult population led to minimized egg laying by $T$. absoluta, spinetoram $12 \mathrm{SC}$ among synthetic chemicals was found effective as a curative measure at higher adult populations in traps. Leaf mining habit, shorter lifecycle, overlapping generations and higher infestations of $T$. absoluta along with serpentine leafminer (Liriomyza trifolii (Burgess) sustain the pest status of SATM on tomato grown in open fields and polyhouses. In addition, fruits transported serve as carriers-cum-source of perpetuation, thus rendering biological or chemical control alone as a difficult proposition. While resistance breeding using wild and cultivated genotypes of tomato should be the long-term strategy, options of IPM should be deployed based on effective monitoring of T. absoluta.

\section{Lessons learnt and the way forward}

The five transboundary insects which have invaded India during the current decade belong to different groups based on metamorphosis (Hemimetabolous: CMB, DL and RSW; Holometabolous: FAW and SATM), feeding habits (defoliators (removal of plant tissues): DL, FAW and SATM; sap feeders: CMB and RSW), host range (narrow: CMB and SATM; wide: DL, FAW and RSW) and migratory potential (high: DL and FAW; low: CMB, RSW and SATM), but share the common feature of ' $r$ ' strategists, wherein the reproductive potential is higher with shorter lifecycle leading to higher abundance allowing their colonization in early successional and disturbed habitats with resultant higher damage to crops. With the exception of DL, where an early warning system allowing preparedness and execution of emergency options exists for their management, the mode of invasion in other cases is often not definitive. The difference between time of documentation following diagnosis of the invaded species and response made to eradicate and delimit their spread (possible often by destruction of severely affected fields/plants and preventing the movement of commodities that serve as carriers) has never been rapid, allowing the species to colonize exploiting the new niche and become a regular pest. Here comes the need for establishing a centralized digital platform for real-time reporting of pest scenarios from across regions/crops by all stakeholders of plant protection ably supported by national diagnostic laboratories.

In India, considerations for management of invasive insects after their establishment have always been scientific and methodical, wherein the search for presence of native natural enemies begins simultaneously with the observations on population development of the invasive insect under field and laboratory conditions. While classical biological control for an invasive insect is a feasibility based on case histories elsewhere in the world, the principle of 'unity in diversity' exploiting the polyphagous native natural enemies of diverse Indian ecosystems through habitat management practices should be the immediate step. A case in point has been the successful management of RSW by exploiting an already available parasitoid (E. guadeloupae). The diverse groups of parasitoids, predators and pathogenic microbes recorded so far on FAW under Indian conditions are numerically higher than the seven approved chemical insecticides, and 
the former should be part of propelling biological control at low to medium populations of FAW in maize/ sugarcane/pearl millet/sorghum fields. Cultural practices such as intercropping offering shelter and alternative food sources are the agro-ecological interventions needed for conservation of native natural enemies ${ }^{4}$. Biocontrol options of inoculative or inundative releases of Trichogramma pretiosum or Telenomous remus coinciding with egg-laying by FAW should be the first line of action. The use of microbial pesticides (Bacillus thuringiensis or Metarhizium anisopliae or Beauveria bassiana or Spodoptera frugiperda nuclear polyhedrosis virus or entomopathogenic nematode formulations) would be the best choice to target larval stage. Selective bioagents against FAW offer scope for their mass production under 'vocal for local' and 'Atmanirbhar Bharat', the policy approaches under the COVID-19 pandemic and beyond. Since accessibility and cost are the main factors relating to bioagents, their internal and need-based mass production should be facilitated through establishment of insectaries at block level by government machineries, rather than the promotion of commercial ventures that are often fraught with low quality and high cost. However, it does not exclude the intake of source materials from outside the country, such as Green Muscle for DL management and exploring options of host-specific parasitoids for invasive insects to be decided case by case. The absence of effective native bioagents against $\mathrm{CMB}$ in India established within six months of its invasion vis-a-vis the success stories of classical biological control using host specific Anagyrus lopezi reported in African and other Asian countries growing cassava must guide the option of importation of the parasitoid with no loss of time.

\section{Conclusion}

The diversified agro-ecosystems, episodes of invasive pests, climate change, research-cum-developmental organizational set-up and industries dealing with plant protection in India have all the required paraphernalia for effective preparedness and management of pest events, whenever they occur. However, the operationalization needs better coordination and active collaborations are necessary for systematized handling of invasive and emerging pests. Slighter adjustments and reorientation in functioning of plant protection stakeholders interlinked through a common hub would uplift the standards of diagnostics, preparedness and pest management. Policy framework facilitating execution of proactive strategies of plant protection by governmental departments with hand-holding of growers and input industries is highly essential. No other time is better than the present for use of mandatory digital platform for pest surveillance and mass media to execute 'better crop health for the best of human health' in food production systems. Enhancing production and income of farmers through reduction of yield losses caused by pests using eco-friendly strategies should be the motto of plant pest management towards fostering national food safety and environmental security. It must also be emphasized that management of transboundary pests requires national, regional and international levels of cooperation and collaboration.

1. NBAIR Pest Alert, Occurrence of cassava mealybug Phenacoccus manihoti Matile-Ferrero in India. ICAR-NBAIR, Bengaluru, 2020; https://www.nbair.res.in/index.php/node/1260.

2. Locust Watch, Desert locust archives, FAO, Rome, Italy, 2020; http://www.fao.org/ag/locusts/en/archives/archive/index.html.

3. Kalleshwaraswamy, C. M., Asokan, R. and Mahadevaswamy, H. M. M., First record of invasive fall armyworm, Spodoptera frugiperda (JE Smith) (Lepidoptera: Noctuidae) on rice (Oryza sativa) from India. J. Entomol. Zool. Stud., 2019, 7, 332-337.

4. Suby, S. B. et al., Invasion of fall armyworm (Spodoptera frugiperda) in India: nature, distribution, management and potential impact. Curr. Sci., 2020, 119, 44-51.

5. ICAR-NBAIR, Rugose spiralling whitefly-Aleurodicus rugioperculatus (Hemiptera: Aleyrodidae), ICAR-National Bureau of Agricultural Insect Resources, 2019; https://www.nbair.res. in $/$ node $/ 833$.

6. Sridhar, V., Chakravarthy, A. K., Asokan, R., Vinesh, L. S., Rebijith, K. B. and Vennila, S., New record of the invasive South American tomato leaf miner, Tuta absoluta (Meyrick) (Lepidoptera: Gelechiidae) in India. Pest Manage. Hortic. Ecosyst., 2014, 20, $148-154$.

7. Kumari, D. A., Anitha, G., Anitha, V., Lakshmi, B. K. M., Vennila, S. and Rao, N. H. P., New record of leaf miner, Tuta absoluta (Meyrich) in tomato. Insect Environ., 2015, 20, 136-138.

8. Locust Watch, Desert locust situation update. FAO, Rome Italy, 2020; http://www.fao.org/ag/locusts/en/info/info/index.html.

9. CABI, Green Muscle providing strength against devastating locusts in the horn of Africa, Centre for Agriculture and Bioscience International, 2020; https://www.cabi.org/news-article/ green-muscle-providing-strength-againstdevastating-locusts-inthe-horn-of-africa/.

10. Joshi, S., Pai, S. G., Deepthy, K. B., Ballal, C. R. and Watson, G. W., The cassava mealybug, Phenacoccus manihoti Matile-Ferrero (Hemiptera: Coccomorpha: Pseudococcidae) arrives in India. Zootaxa, 2020, 4772, 191-194.

11. Anon., 'Foreign pest' threat to tapioca crops in South India, 2020; http://www.dextrainternational.com/foreign-pest-threat-to-tapiocacrops-in-south-india/

12. Karyani, R. D., Maryana, N. and Rauf, A., Host specifity test of parasitoid Anagyrus lopezi (De Santis) (Hymenoptera: Encyrtidae) on four mealybug species associated with cassava. Indones. J. Entomol., 2016, 13, 30-39.

13. Wyckhuys, K. A. G. et al., Continental-scale suppression of an invasive pest by a host-specific parasitoid underlines both environmental and economic benefits of arthropod biological control. Peer J., 2018, 6, e5796.

14. Shylesha, A. N., Sunil, J., Rabindra, R. J., Prakya, S. K., Kolla, S. and Chandish, R. B., Biocontrol Bears Fruit: Saving Papaya from the Mealybug. ICAR-NBAIR, Bengaluru, 2018; https://mail. google.com/mail/u/0/\#inbox/FMfcgxwJXpVWFVshjchQGnpDzPvNFhxC? projector $=1 \&$ messagePartId $=0.1$.

15. Shylesha, A. N. et al., Studies on new invasive pest Spodoptera frugiperda (JE Smith) (Lepidoptera: Noctuidae) and its natural enemies. J. Biol. Control, 2018, 32, 145-151.

16. Gupta, Ankita, Lalitha, Y., Varshney, Richa, Shylesha, A. N. and Cornelis, Van., Chelonus formosanus Sonan (Hymenoptera: 
Braconidae), an egg-larval parasitoid of the invasive pest Spodoptera frugiperda (JE Smith) (Lepidoptera: Noctuidae) amenable to laboratory mass production in India. J. Entomol. Zool., 2020, 8, 1521-1524.

17. Gupta, Ankita, Lakshmi, P., Soujanya and Sekhar, J. C., Coccygidium transcaspicum (Kokujev) (Hymenoptera:Braconidae) parasitizing larvae of invasive pest Spodoptera frugiperda (JE Smith) (Lepidoptera: Noctuidae) in India. Zootaxa, 4750, 2020; https:// doi.org/10.11646/zootaxa.4750.2.13.

18. Shylesha, A. N. and Sravika, A., Natural occurrence of predatory bugs, Eocanthecona furcellata (Wolff) and Andrallus spinidens (Fabr.) on Spodoptera frugiperda (Smith) (Hemiptera: Pentatomidae) in maize and their potential in management of fall armyworm. J. Biol. Control, 2018, 32, 209-211.

19. Sivakumar, G. et al., Isolation and characterization of indigenous nucleopolyhedrovirus infecting fall armyworm, Spodoptera frugiperda (JE Smith) (Lepidoptera: Noctuidae) in India. Curr. Sci. 2020, 119, 860-864.

20. ICAR-NBAIR, Absorption and delivery of molecules using nanoporous materials, 2020; https://www.nbair.res.in/ITMU/tech details.php?id=21.

21. DPPQ, Advisory on incidence of fall armyworm (FAW) Spodoptera frugiperda on maize in Himachal Pradesh, Directorate of Plant Protection Quarantine and Storage, Directorate of Plant Protection Quarantine \& Storage, Government of India, 2020, pp. 1-3; http://ppqs.gov.in/sites/default/files/advisory_1_0.pdf.

22. ICAR-NCIPM, Mobile App on fall armyworm integrated pes management (Faw_ipm), ICAR-National Research Centre for Integrated Pest Management, 2020; https://play.google.com/store/ apps/details?id=nic.faw_ipm\&hl en_IN.

23. Varshney, R. et al., Biocontrol-based management of fall armyworm, Spodoptera frugiperda (J E Smith) (Lepidoptera: Noctuidae) on Indian maize. J. Plant Dis. Prot., 2020; https://doi.org/ 10.1007/s41348-020-00357-3.

24. FAO, Fall armyworm: Global action for fall armyworm control. Food and Agriculture Organization of the United Nation, Rome, Italy, 2020; http://www.fao.org/fall-armywormhttps://doi.org/ 10.7717 peerj.5796.

25. CABI, Invasive Species Compendium - fall armyworm, Centre for Agriculture and Bioscience International, 2020; https://www. cabi.org/isc/fallarmyworm.

26. Anon., Response to pests and diseases. 2020; https://www. growasia.org/full-armyworm-control.
27. Ramani, S., Poorani, J. and Bhumannavar, B. S., Spiralling whitefly, Aleurodicus disperses in India. Biocontrol. News Inf., 2002, 23, 55-62.

28. Mani, M., Origin, introduction, distribution and management of the invasive spiralling whitefly Aleurodicus dispersus Russell in India. Karnataka J. Agric. Sci., 2010, 23, 59-75.

29. Poorani, J. and Thanigairaj, R., First report of Encarsia dispersa Polaszek (Hymenoptera: Aphelinidae) as a parasitoid of rugose spiralling whitefly, Aleurodicus rugioperculatus Martin (Hemiptera: Aleyrodidae), a recent invasive pest in India, with notes on its predators. J. Biol. Control, 2017, 31, 1-4.

30. Selvaraj, K., Sundararaj, R., Venkatesan, T., Ballal, C. R., Jalali, S. K., Gupta, A. and Mrudula, H. K., Potential natural enemies of the invasive rugose spiraling whitefly, Aleurodicus rugioperculatus Martin in India. J. Biol. Control, 2016, 30, 1-4; doi: 10.18311/jbc/0/0/15598.

31. ICAR-NBAIR, ICAR-NBAIR curtails dangerous invasive rugose spiralling whitefly through innovative biocontrol Strategies, ICAR-National Bureau of Agricultural Insect Resources, 2020; https://icar.org.in/content/icar-nbair-curtails-dangerous-invasiverugose-spiralling-whitefly-through-innovative- 0 .

32. Ballal, C. R., Gupta, A., Mohan, M., Lalitha, Y. and Verghese, A., The new invasive pest Tuta absoluta (Meyrick) (Lepidoptera: Gelechiidae) in India and its natural enemies along with evaluation of Trichogrammatids for its biological control. Curr. Sci., 2016, 110, 2155-2159.

33. Sridhar, V. et al., Efficacy of integrated pest management tools evaluated against Tuta absoluta (Meyrick) on tomato in India. J. Biol. Control, 2019, 33, 264-262.

ACKNOWLEDGEMENTS. S.V. gratefully acknowledge the contribution of the co-authors for the compilation and summarizing the information and image resources accessed from the National Bureau of Agricultural Insect Resources, Bengaluru/Directorate of Plant Protection Quarantine and Storage, New Delhi involved in the identification and management of these transboundary insects of national significance.

Received 7 October 2020; revised accepted 7 December 2020

doi: $10.18520 / \mathrm{cs} / \mathrm{v} 120 / \mathrm{i} 8 / 1308-1314$ 